\title{
Czechoslovakian Crystal in Pavlova Paradise: Vladimir Čačala, 1926-2007
}

\section{Linda Tyler}

Characterizing New Zealand as the half-gallon, quarter-acre, pavlova paradise in 1972, British writer Austin Mitchell distilled the essence of national aspiration (Mitchell, 1972). During the Holyoake years, a detached house on a separate parcel of land had somehow become identified with what it meant to be a true New Zealander. Low-interest State Advances loans after the Second World War meant that this ideal suburban existence was an achievable goal even for those on low incomes. But as a writer in Design Review cautioned in 1953, over 40 percent of the population of cities were people "for whom a detached house standing in its own grounds is not necessarily the most practical proposition. Its maintenance is too costly in terms of time, money or ability" (Your New House, 1953: 88). The writer advocated building flats as an alternative:

Multi-unit housing development in the cities is as important to the economy of the country as a single-unit development in the suburban areas; such development has sometimes been carried out successfully in the past but it carries the stigma of the overcrowded slum with it. The need for well-designed flats is more pressing than ever before and the people who need them most are least in a position to finance their erection. This must be a task for local or national government, or for the larger private investment agencies. (Your New House, 1953: 88)

High-density housing was considered foreign, associated with Europe and hard to assimilate, although the Labour Government had undertaken experiments with large-scale rental developments in cities in the 1940s. Austrian architect Ernst Plischke later reported that the New Zealand suspicion about apartment blocks was that only prostitutes or intellectuals wanted to live in them. ${ }^{1}$ Housing these particular groups within the larger society was not a priority for post-war planners.

With the change of government to National in 1949, opportunities arose for private investors to develop urban blocks to accommodate flats that would be affordable for low-to-middle income groups. In Auckland, émigré Czechoslovakian architect Vladimir Čačala (1926-2007) (Fig. 1), ${ }^{2}$ who arrived in the city at the end of 1952, spearheaded this development. Well-recognized for his glamorous avant-garde designs for homes such as the Blumenthal House (1958), Čačala is less well-known for his pioneering of the new materials and methods of modernism to produce a higher density of housing for private clients. In this article, Čačala's biography is sketched and his most significant designs for houses, factories, shops and churches are assayed against the proposition that the extent of his involvement in multi-unit design had implications for his modernism.

Appropriately enough - since apartment blocks were considered fit only for bohemians in New Zealand - Čačala was an immigrant from the country previously known as Bohemia. Vladimir Oldrich Čačala was born in Prague in 1926, only
The author would like to acknowledge the considerable help she had in preparing this article from Vladimir Čačala's four daughters: Shas Čačala, Liza Clark, Tanya Healey and Vicki Wallace.

I In his self-published memoir, Plischke recalls the words of a visiting housing official: "In Auckland leben nur Prostituierte und Intellektuelle in flats" (Plischke, 1989: 283). This is corroborated by Cedric Firth who wrote in 1949 . "To the ordinary citizen, the term 'flat' is indelibly associated with a tall barrackslike structure with poor accommodation and poor appearance and with little to commend it.... A title, then, is required to cover flats planned to meet the modern requirements of the family - a title devoid of so many unattractive associations. It is hoped that the term 'multi-unit' will suffice" (Firth, 1949: 37).

2 Born 23 March 1926, married 9 May 1957, died 27 May 2007. 
Fig. 1: Vladimir Oldrich Čăčala. Čăcăla
Family Collection. 3 The furniture of Bohemian cabinet maker and marquetarian Anton Seuffer
(1815-87), who arrived in Auckland 1859, exemplifies this fine woodworking

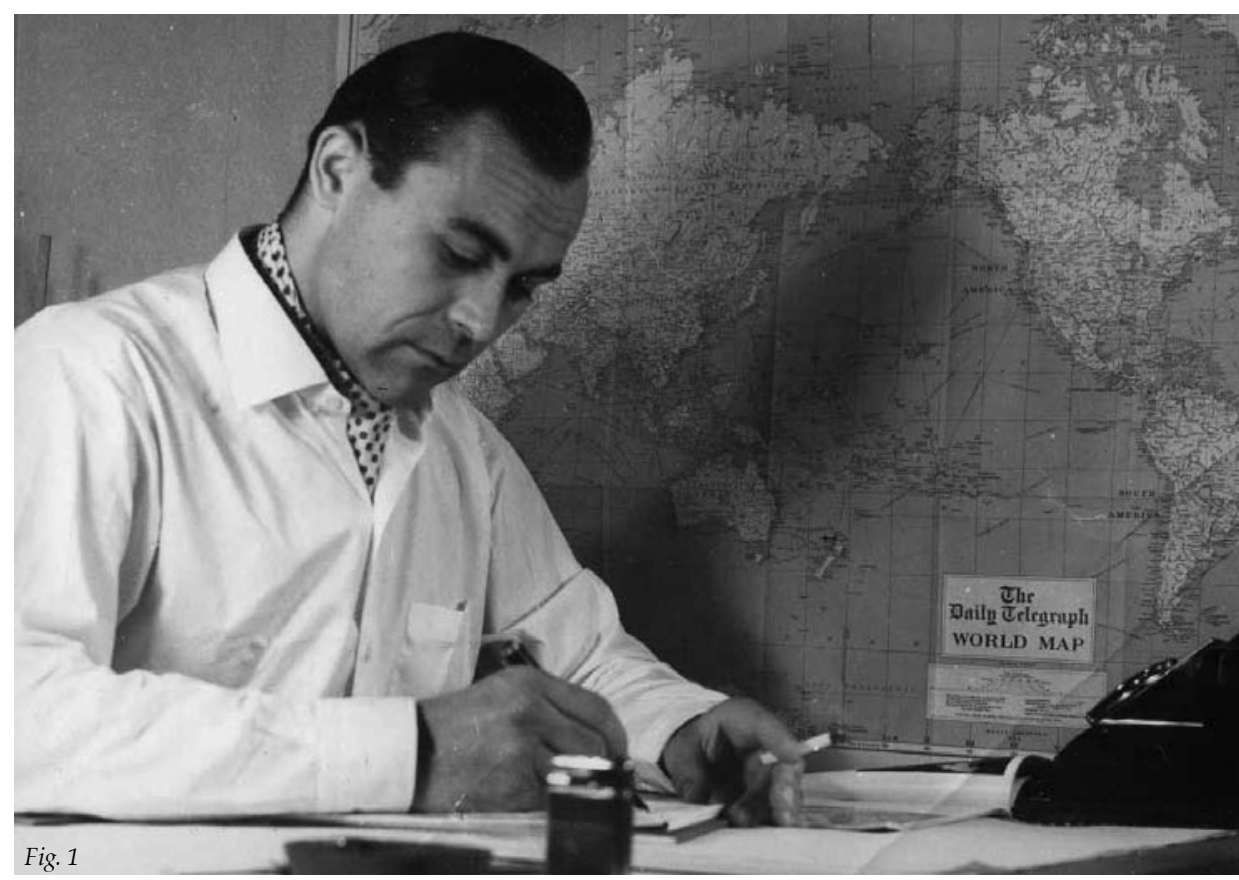

eight years after the Austro-Hungarian Empire had ended with the defeat of Germany in 1918. The new union of Bohemia, Moravia and Slovakia created one of Europe's most industrialized countries, and by the 1930s, Czechoslovakia was at the forefront of new thinking about architecture, design and the application of modern technologies. Wooden furniture, and in particular marquetry, had long tradition in the region, but was beginning to be superseded by a demand for chrome-plated steel and lacquer promoted by the Exposition Internationale des Arts Décoratifs et Industriels Modernes held in Paris in $1925 .{ }^{3}$

As well as changing the face of Czechoslovakian furniture, prosperity facilitated controversial architecture. In Prague, building was controlled by a central planning authority which favoured proposals for projects that could express the prestige of the city through dramatic design. As the middle child born to furniture manufacturer Vladimir T. Čačala, the young V. O. Čačala had a privileged insight into contemporary design in the capital city. He visited many of the newly built and most remarkable examples of architecture with his father including Adolf and 'Vill Mueler (1930) and the Dutch architect Mart Stam's Palick House (1932), which was part of the Baba Housing Estate (1928-40), hiechequivalen of the Weissenhofsiedlung. A three-hour bus ride away was Mies van der Rohe's Tugendhat House (1930) in Brno. Built with a steel and concrete skeleton frame with screens of translucent onyx and marquetry in exotic woods on the interio the most impressive feature of the Tugendhat House for the young boy was that the glazing at the front had been designed to retract into the floor to turn the whole living space into an elevated porch.

These informal lessons in modernism were interrupted, along with Čačala's formal education, in the late 1930s wh remained closed for six years during the Second World War. Invaded, annexed and generally appropriated by Nazi Germany, Czechoslovakia was not liberated by the Red Army until 1944. Cačala enrolled at the Czech Technical University in Prague when teaching resumed on 4 June 1945, under Professor Emil Králik (1880-1946). Karel Prager (1923-2001) and Karel Hubacek (born 1924), who would later be acclaimed for their use of new materials and structural elements, were also students at the time. Interviewed in 2004, Čačla described his architectural training in post-war Prague as being heavily influenced by the Bauhaus:

When the Bauhaus was closed by Hitler in 1933, all the students and the professors spread away from Germany. A lot went to Prague and that's where I was lucky. I had those teachers to learn the clean lines and the simplicity from. The architecture school in Prague was more or less run by the guys who were Bauhaus. (Binsley, 2004: 72)

For many Europeans of Čačala's generation, the Bauhaus ${ }^{4}$ introduced the concept of the design studio as a kind of industrial laboratory, where ideas for mass production could be trialled. Marcel Breuer's cantilevered armchairs, which were made of tubular steel and leather and were light, transparent and easily moved, with the base of the frame acting as a skid, epitomized the Bauhaus aesthetic.

Neither Fascism nor Marxism proved conducive to modernist architectural design. Czechoslovakia became a satellite state of the Soviet Union in February 1948. The economy was committed to centralized planning, and private architectural practice was banned. Čačala's father was denounced as an enemy of he people, his factory was closed and he disappeared. Seven months later, in September 1949, his son escaped across the border to American-occupied Bavaria. From there he travelled to Hamburg and in 1950, with the assistance of the United Nations International Refugee Organization, he gained passage to Melbourne from Naples on board the Sitmar liner Fairsea. ${ }^{5} \mathrm{He}$ travelled under the Displaced Persons Programme which brought 170,000 immigrants to Australia between 1947 and 1953. In Sydney, Čačala worked as an architectural draughtsman before discovering that his father, who had left Czechoslovakia six months efore, ha alre reunited in Anckland, acity of about 300,000 people.

As an industrial designer with skills in plywood furniture manufacture from his years working in his father's factory, Čačala had no difficulty finding employment. He joined the architectural partnership of Brenner Associates ${ }^{6}$ which had been formed in 1949. Des Mullen, Stephen Jelicich and Milan Mrkusich (the latter two of Dalmatian-Croatian descent) had been joined by Ron Grant in 1950, and worked mostly on interior fit-outs, with their showroom at 79 Hobson Street. Čačala found Brenners the ideal vehicle for his ideas about modern architecture and he became a design partner in 1954. He soon found his first independent clients as well. Austrians Ernst Gelb and his wife Ilse, a seamstress, had arrived in New Zealand as refugees from Hitler in 1939 and prospered. They bought a north-facing section in Mt Albert Road, opposite historic Alberton, and sought to build a sophisticated house which reflected their European origins. Perched atop solid man a bap a solid and has a flat roof. A the length of the house at the back, opening up the living room and master bedroom to the distant views and sunlight through French doors (Reid, 1992: 75-83).

Two years later, in 1958, Čačala was commissioned by fellow Czechoslovakian émigré Ernest Blumenthal and his Canadian speech therapist wife Rachel Raye Blumenthal (née Ginsberg) to design a contemporary house for modern living (Figs. 2, 3 and 4). ${ }^{6}$ On a private St Heliers section with panoramic views, Čačala
4 At the Bauhaus in Dessau in 1927, an ral department had been set

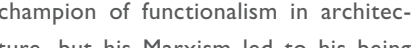
replaced as diretor in to to his being Mies van der Rohe (1886-1967).

The passport issued to Vladimir Oldis dated 2 January 1950.

6 Named for the mountain pass through the Alps between Italy and Austria, where Mussoinin and Hitler met to celebrate Another Czech Architect, Heinrich Tha (1900.M), had been the best man tornest Blumenthal's wedding, yet it the house. 
Fig. 2: Blumenthal House, 1958. Fir. 3: Blumenthal House at night. Photograph by Ted
Fanily Collection. Fig. 4: Plans of the Blumenthal House,
1958. Cacáala Family Collection.
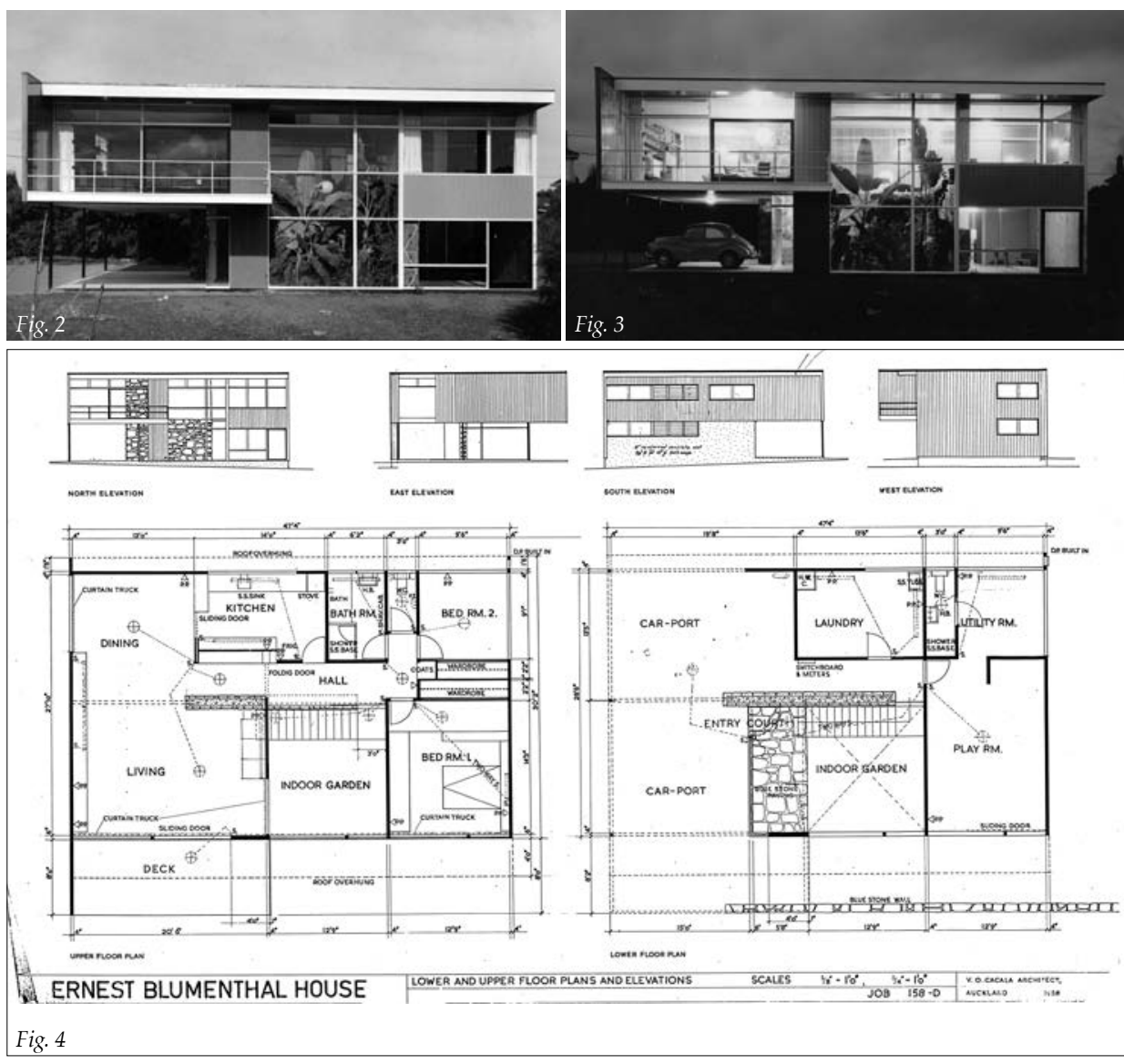

created the masterpiece that has earned him his place in the annals of practitioners of the International Style in New Zealand. Making spectacular use cantilevering and large areas of glass, the Blume Mal House creates t cantileveng and large are sion of hanging living area, and the front door opens into an indoor garden, lush with banana plants and tropical palms. This entry is a two-storeyed space which provides light into the hall and the west wall of the living room. At the back, a wal of dark stone anchors the house centrally, with timber stair treads supported on steel members cantilevering out from it. As with some of his later blocks of flats, here the staircase in its garden has a space-forming role, creating a heart for the whole building from which the other areas are derived.

Čačala's use of bluestone cladding on the staircase wall in the Blumenthal House, to create a centre of power for the house, derives from European prototypes. Like the marble walls of Mies van der Rohe or the Utah rock used by Richard Neutra for the interior of his desert homes, Cačala's volcanic stone is both functional and decorative. Sourced locally in a typically modernist fashion, this indigenous material relates the house to its Auckland geological context. Rather then it becoming a heavy, dark presence in the house, its surface is enlivened presenened with white pointing in the living preor are. His bine natural and cultural references. Built-in furniture in the bedrooms and wall panelling have a mahogany veneer, while the cabinets in the living area were painted red, grey, white and black and suspended miraculously clear of the floo being dubbed a "suspended utility entertainment wall". Like the dark-staine timber houses of Vernon Brown and the Group from this period, Čačala finished
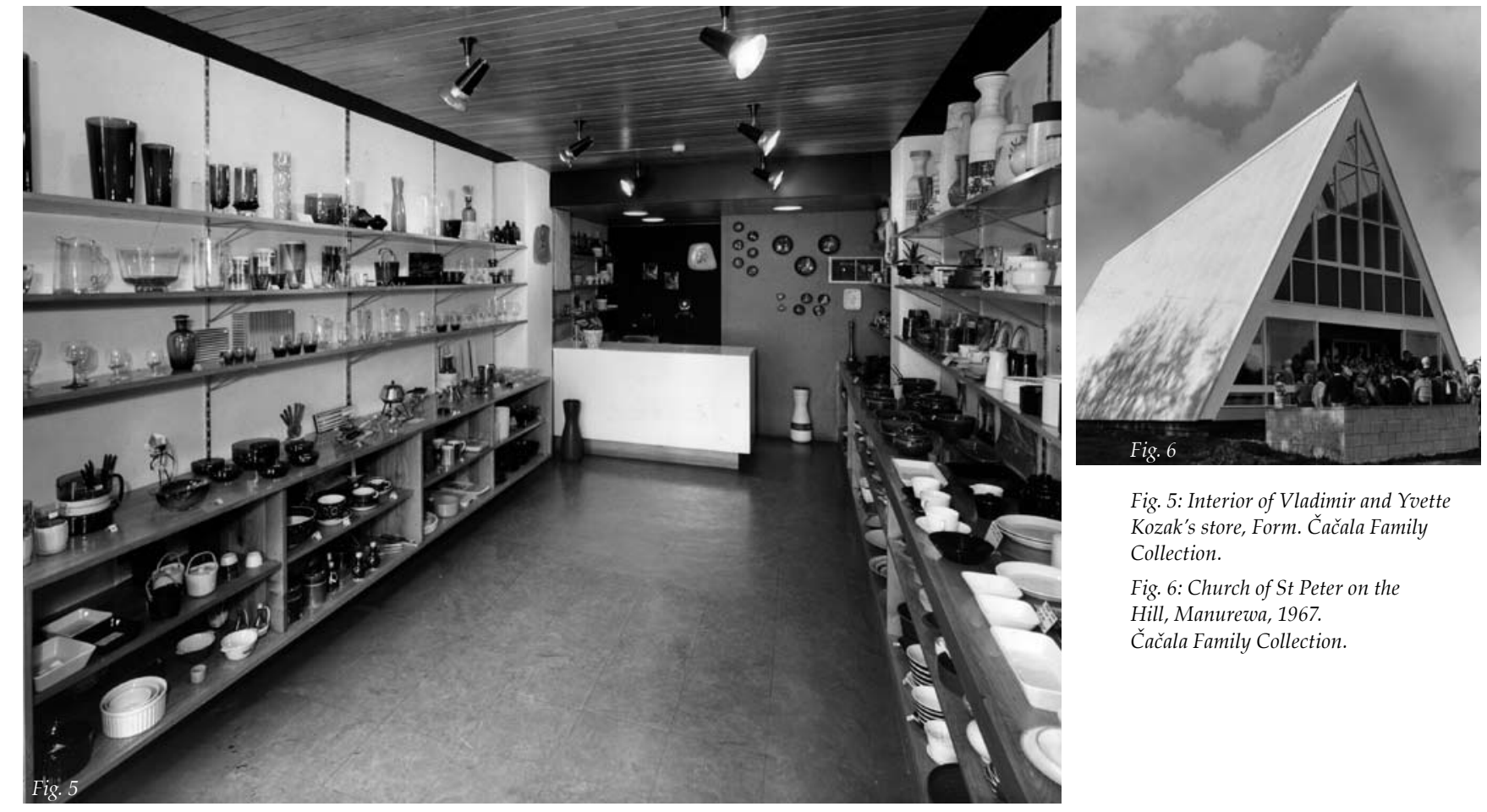

Fir. 5: Interior of Vladimir and Yvette Kozak's store
Collection. Fig. 6: Church of St Peter on the Hill, Manurevou, 1967.
Čacala Family Collection.

the external vertical cedar cladding on three sides of the house with a mixture of creosote and Stockholm tar, but painted the front with bands of primary colours. As a result, the north elevation was thought by the international architectural press to resemble a composition by the Dutch De Stijl painter, Piet Mondrian. Named the Mondrian House, it featured in the prestigious Los Angeles periodical, Arts and Architecture, which had Marcel Breuer, Walter Gropius and Richard Neutra as editorial advisors (House in New Zealand, 1960: 26); as well as in Gio Ponti's Domus, published in Milan (Il Verde "Fuori Scala", 1962: 47); and the local magazine, The Mirror (Interior-Exterior Harmony, 1961: 50-51, 58). ${ }^{8}$

Čačala's reputation was assured with this commission, and he set up his own architectural practice in partnership with Walter Leu in 1959. As Čačala, Leu Associates, they created high modern design for fashionable clients: an interior for Vladimir and Yvette Kozak's store, Form, in High Street (Fig. 5); and a fitout for the Blumenthal's coffee shop on Queen Street, the Kottage Kake Kitchen. The partnership was also responsible for the design of a factory for men's tie manufacturer John Webster in Exmouth Street (John Webster \& Co, 1963: 12). In Otara, South C. Goode and Co. which maximized natural hight Goode \& Co., 1967: 58-59), as well as the radical A-framed Church of St Peter on the Hill (Fig. 6) and the Church of St Albans with exposed steel structure, both in Manurewa and both designed in 1965 (Bond, 1965). Featuring in the Parade of Homes in Manurewa in 1964 was the remarkable exhibition house Contempora with two-storey lounge and windowless brick west wall, which, like the Blumenthal House, had an indoor garden that extended under the stairs (Exhibition House, 1966: 34-37). The Kay House (1959) in Victoria Avenue, Remuera (Uncluttered Look, 1965: 11). Cačala's own house in Lucerne Road (1959) (Sensitive Unity, 1963. 20) and houses designed for his friend Bernd Koningham (Konigsheimer) classic domestic designs for a New Zealand lifestyle (Fig. 7).
8 The Ladies' Mirror (1922-26) was superseded by The National Home Journal which was pubWhed by Henry Kelliher of Dominion Preveries as a vehicle for his views on March 1963 


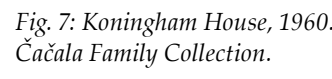

9 Rents are documented as $67.10 \mathrm{~s}$ for a one-bedroomed and
bedroomed flat in 1967 .

10 Jointly developed by Čăăal with the Blumenthals as investors, this schen comprised six who-bedroomed and three living rooms faing over the city and Waitemata Harbour.

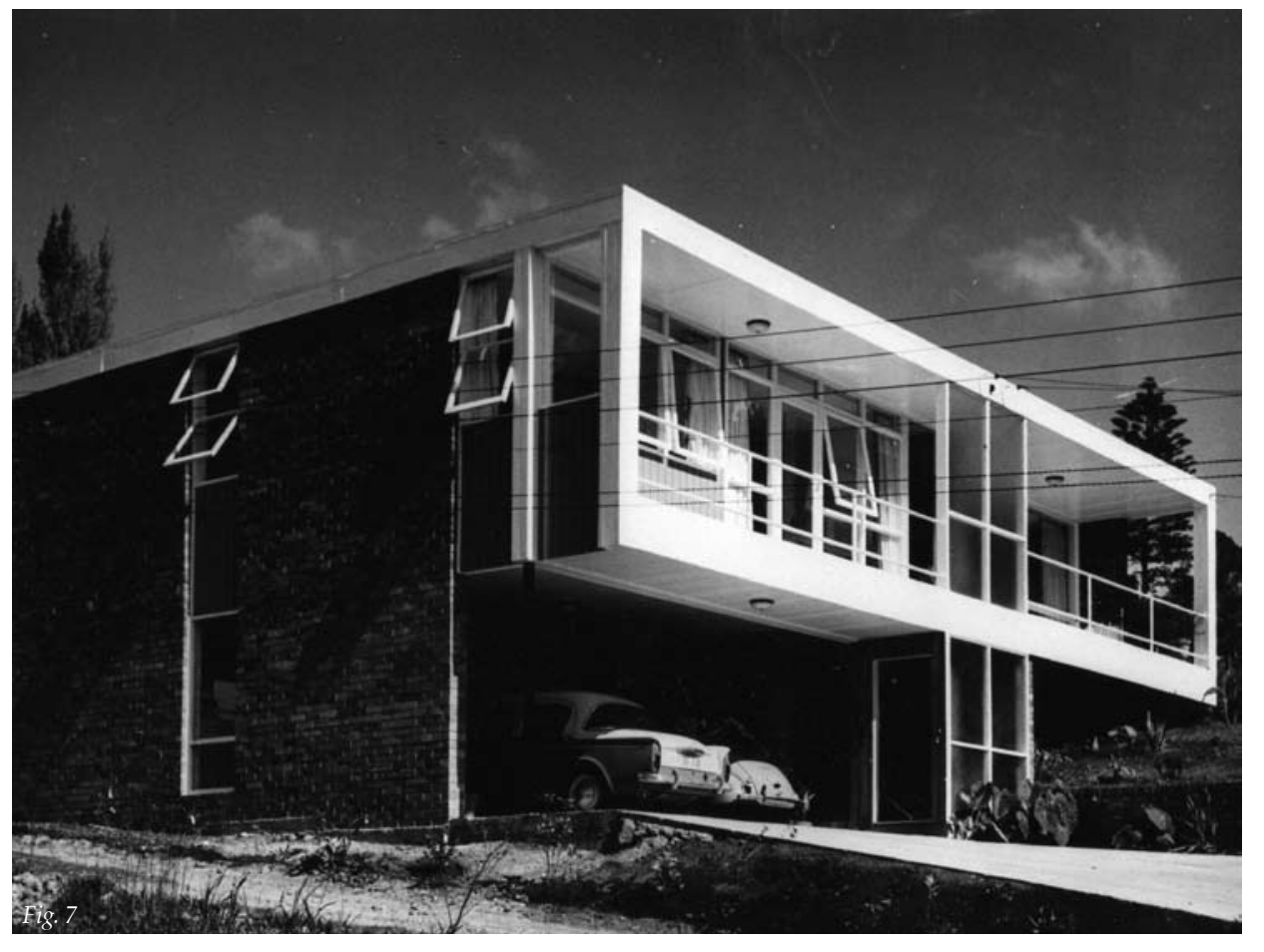

The distinguished designs for individual houses from the 1950s have somewhat eclipsed Cacala's reputation for multi-units later in his career. He had a longterm interest in rental housing, and even his most glamorous homes often included self-contained flats which could be rented out to provide owners with income. Providing his fellow investors with good returns ${ }^{9}$ Cačala's approach was bold and innovative. In his multi-units, it is possible to see an antipodean (S) paralle to signs in Illinois, where the introduction of externally projecting mullions at the module reference points makes the elements of the building's structure visible. As early as 1954, Cačala built his first block of four two-bedroomed apartment at 100 St Stephen's Avenue in Parnell. Using first brick, then concrete and finally reinforced concrete block in combination with large areas of glass, Čačala moved towards a Miesian fusion of structure with transparency over the next twenty years.

Unlike Mies, his uppermost concern was always affordability. With his first multi-units, he took care to comply with the conditions for a State Advances loa by keeping the cost of each to $£ 1000$ so that they could be individually purchased. His next development of eighteen one-bedroomed flats at 16-18 St Stephen's Avenue complied with the Town Planning Department's restriction on the number of occupants zoned for that area of land but was also a commercial proposition by increasing the density of development, often beginning by buying a section with a single house, removing it and building multi-units in its stead. This approach is epitomized by the reinforced brick Paritai Drive development of 196 (Fig. 8). Similarly, the 'Seabreeze' flats at Birdwood Crescent ${ }^{10}$ represented a kind of system-built housing, based on European models. Constructed in reinforced concrete block with Winstone Vibradec floors and long-run roofing, these flats were quickly and economically erected, and were the prototype for the largerscale apartment buildings. Cačala's confidence in the potential of his materials

Home Units in Paritai Drive, 1965

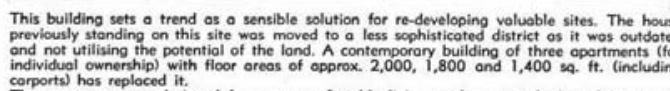

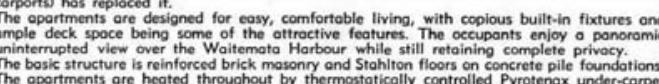

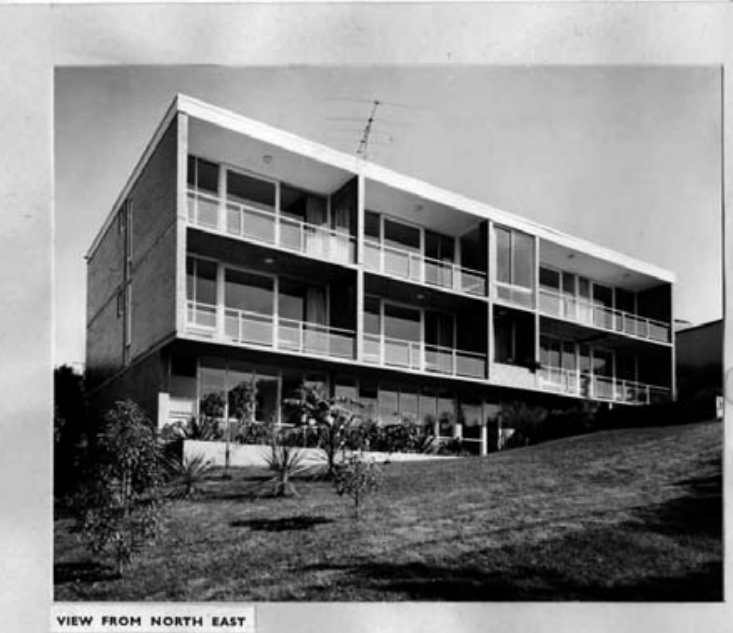

Fig. 8 vew mon Morru us

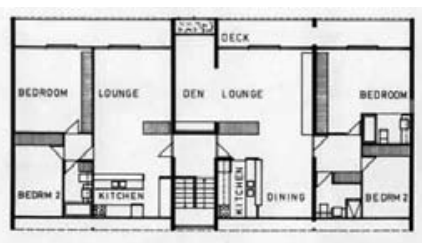

UPPER FLOOR

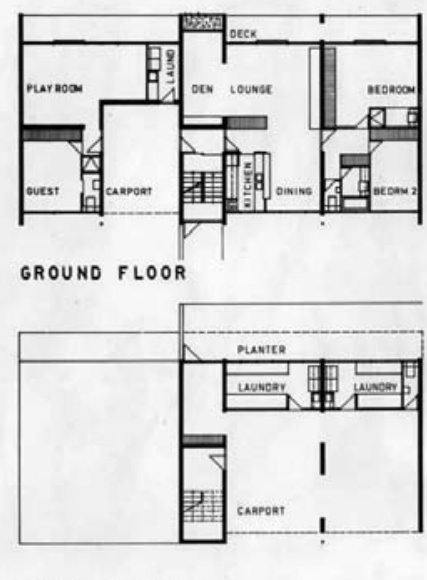

LOWER FLOOR
Fig. 8: Home units in Paritai Drive,
1965. Čačala Family Collection.

to extend to high-rise developments continued to grow. A 27-unit block of flats at 49 St Stephens Avenue was completed in 1969-70. Next, for E. Lichtenstein \& Co Ltd., an Onehunga Wool scouring company, he designed the six-storey block of 60 one-bedroomed flats in Gladstone Road, Parnell (now the Barrycourt Motel), nineteen flats at the corner of Kepa Road and Kupe Street in Orakei was finished proving the reliability of the material and even (controversially) slightly exceeding the height restriction for the area.

A cursory tally of the developments listed in Čačala's job book for the two prosperous decades from 1954 until 1978 shows that the inner-eastern suburbs of Auckland were populated with over twenty Čačala-designed apartment blocks, with others appearing on the North Shore and in Herne Bay. ${ }^{11}$ Generously proortioned, with floor areas typically of 1400, 1600 and 2000 square feet (or 131, 150 and 185 square metres), these were distinctive and luxurious flats, which eter Shaw describes as presenting a "convincingly 'modern' look to their inhabitants. Much use was made of textured wall finishes, including hessian, exposed aggregate and a variety of sprayed-on surface finishes, which could be highly effective if used sparingly." Shaw concludes, "Cacala, employing a minimal anaunified effect in matters of form, texture and colour" (1991: 125).

This tendency towards standardization shows that as a European modernist working in New Zealand in the post-war period, Čačala endeavoured to overcome distance by reterating the Bauhaus aesthetic which had nurtured him. is interpretations of this abstraction in the local context were circumscribed by he limited tastes and resources of his period, but amongst his fellow émigrés he found a sympathetic clientele. His multi-units introduced the principles of functionalist architecture to the private housing development context. The re-
II The job book includes the following 100 St Stephen's Avenue, Parnell 588 Eighteen one-bedroomed apartments, $16-18$ St Stephen's Avenu
Parnell 1960 Fifteen one-bedroomed apartParne 1962 Seafield Flats, nine apartments 1922 Two apa
Orakei

262 Fifteen apartments, Milford Ro 1963 Four apartments, Glendowi 1963 Rodnal flats and house Eight apartments, Gillies Avenue Epsom 1964 Six apartments with shops, Coates Avenue, Orake Drive, Orak 196427 apartments (eight studio,
eleven one-bedroomed, seven (wo-bedroomed and a penthouse, 49 St Stephen's Avenue, Parnell 1965 Apartments

Eson

Thirty apartments, View Road,
Mt BEden

Edenvale Road, Mt Eden 198 Thirty apartments, 49 Esplar 1963 Apartments, Hamilton Road, 1964 Three apartments, 5 Hempto 
Road, Mt Eden

1970 Eighteen two-bedroomed apartments, 9a Esplanade Road, Mt Eden

1970 Fifty apartments, 33a Edenvale Crescent, Mt Eden

1970 Sixty-one apartments, 18 Gladstone Road, Parnell (now Barrycourt Motel)

1973 Two flats and a house for $\mathrm{Mr}$ Bennett, 69 Ngapuhi Road, Remuera

1973 Five apartments, 33 Arthur Street, Ellerslie

1973 Four apartments, 12 Coleridge Street, Grey Lynn

1974 Northcrest Apartments, 160 Kepa Road, Orakei sulting architecture responded to the reality of commercial imperatives without compromising the way in which the visual logic of the architecture derived from the qualities of materials and the nature of construction processes. By maintaining the aspirations of modernism in this way, Čačala demonstrates his lasting commitment to the International Style, creating a crystalline architecture which endures in its pavlova paradise setting.

\section{References}

Binsley, J. (2004). Straight Edge. New Zealand Home and Entertaining, (August-September), 72 .

Bond, S. (1965, July 24). Church Affairs: Plans for Two New Manurewa Churches; Latest Styles. Auckland Star. Čačala Family Collection.

Exhibition House at Manurewa (1966). New Zealand Home and Garden, (November), 34-37.

Firth, C. (1949). State Housing in New Zealand. Wellington: Ministry of Works.

G. C. Goode \& Co. Ltd, Factory at Otara (1967). Home and Building, 29(12), cover, 58-59.

House in New Zealand by V. O. Cacala, Architect (1960). Arts and Architecture, (December), 26.

Il Verde “Fuori Scala" (1962). Domus, 391(6), 47.

Interior-Exterior Harmony Created by Planting an Indoor Garden and Repeating Inside Colour Outdoors (1961). The Mirror (August), 50-51, 58.

John Webster \& Co., Factory at Exmouth Street (1963). The New Zealand Draper, 43(517), 12.

Mitchell, A. (1972). The Half-Gallon Quarter-Acre Pavlova Paradise. Christchurch: Whitcombe \& Tombs.

Plischke, E. A. (1989). Ein Leben mit Architektur. Vienna: Locker Verlag.

Reid, G. E. (1992). Vladamir [sic] Cacala and the Gelb House (1955). Interstices, (2), 75-83.

Sensitive Unity Emphasized by Auckland Architect Vlad Cacala (1963, June 10). Auckland Star, p. 20.

Shaw, P. (1991). New Zealand Architecture from Polynesian Beginnings to 1990. Auckland: Hodder \& Stoughton.

Tyler, L. (2007). Vladimir Oldrich Čačala, Architect, 1926-2007. Architecture New Zealand, (September-October), 29-30.

The Uncluttered Look - Inside and Out (1965, November 13). Auckland Star, p. 11.

Your New House ... Or Would a Flat Suit You Better? (1953). Design Review, 5(4), 88-89. 